GRASAS Y ACEITES 71 (2)

April-June 2020, e354

ISSN-L: 0017-3495

https://doi.org/10.3989/gya.0450191

\title{
Determination of functional compounds in blue shark (Prionace glauca) liver oil obtained by green technology
}

\author{
D.N. Santos ${ }^{\mathrm{a}}$, F.S. Silva ${ }^{\mathrm{a}}$, A.B. Verde ${ }^{\mathrm{a}}$, G.M. Bittencourt ${ }^{\mathrm{a}}$ and A.L. de Oliveira ${ }^{\mathrm{a}, \bigotimes}$ \\ ${ }^{a}$ Laboratório de Tecnologia de Alta Pressão e Produtos Naturais (LTAPPN), Department of Food Engineering, \\ Faculty of Animal Science and Food Engineering, University of São Paulo (FZEA/ USP). Av. Duque de \\ Caxias Norte, 225, Jardim Elite, Caixa Postal 23, CEP 13635-900, Pirassununga, SP, Brasil. \\ Corresponding author: alelopes@usp.br
}

Submitted: 04 April 2019; Accepted: 24 April 2019; Published online: 19 May 2020

SUMMARY: The objectives of this research were to obtain blue shark liver oil using supercritical $\mathrm{CO}_{2}$ and to characterize the physicochemical parameters of the oil, and the contents of squalene and vitamin A. Supercritical extractions were performed at 50 and $60{ }^{\circ} \mathrm{C}$ and pressures from 100 to 300 bar. The oil yield obtained was up to $60 \%$ and presented a profile equivalent to that of refined oils for density $(0.920-0.922 \mathrm{~g} / \mathrm{mL})$; viscosity (52.55 - 56.47 Pas.s); refractive index (1.4760 - 1.4785); acid value (1.13 - 2.22\% oleic acid); peroxides (10.47 - $24.04 \mathrm{meq}$ of active $\mathrm{O}_{2} / \mathrm{kg}$ of oil); saponification value $(171.37-556.03 \mathrm{mg} \mathrm{KOH} / \mathrm{g}$ oil), and iodine value $\left(120.05-149.21 \mathrm{~g} \mathrm{I}_{2} / 100 \mathrm{~g}\right.$ oil). The fatty acid profile indicated a majority of unsaturated fatty acids. High levels of squalene and vitamin A corroborate the high nutritional quality of this oil from an underexploited byproduct with great processing potential.

KEYWORDS: Blue shark; Squalene; Supercritical extraction; Vitamin A

RESUMEN: Determinación de compuestos funcionales en aceite de hígado de tiburón azul (Prionace glauca) obtenido mediante tecnología verde. Los objetivos de esta investigación fueron obtener aceite de hígado de tiburón azul utilizando $\mathrm{CO}_{2}$ supercrítico y determinar los parámetros fisicoquímicos del aceite, el contenido de escualeno y vitamina A. Las extracciones supercríticas se realizaron a $50{ }^{\circ} \mathrm{C}$ y $60{ }^{\circ} \mathrm{C}$ y presiones de 100 a 300 bar. Los aceites obtenidos con hasta $60 \%$ de rendimiento presentaron un perfil equivalente al de los aceites refinados para los parámetros: densidad $(0,920-0,922 \mathrm{~g} / \mathrm{mL})$; viscosidad $(52,55$ - 56,47 Pas.s); índice de refracción (1.4760 - 1.4785); acidez (1.13 - 2.22\% de ácido oleico); peróxidos (10,47 - 24,04 meq de $\mathrm{O}_{2}$ activo / kg de aceite); índice de saponificación (171.37 - $556.03 \mathrm{mg} \mathrm{KOH/g}$ de aceite) e índice de yodo $(120,05-149,21 \mathrm{~g} \mathrm{I} / 2$ 100g de aceite). El perfil de ácidos grasos indica una mayoría de ácidos grasos insaturados. Los altos niveles de escualeno y vitamina A corroboran la alta calidad nutricional de este aceite obtenido de un subproducto subexplotado con un gran potencial de procesamiento.

PALABRAS CLAVE: Escualeno; Extracción supercrítica; Tiburón azul; Vitamina A

ORCID ID: Santos DN https://orcid.org/0000-0002-7062-3049, Silva FS https://orcid.org/0000-0001-5074-9325, Verde AB https://orcid.org/0000-0001-8096-8203, Bittencourt GM https://orcid.org/0000-0001-6863-1077, Oliveira AL https://orcid.org/0000-0002-2977-6000

Citation/Cómo citar este artículo: Santos DN, Silva FS, Verde AB, Bittencourt GM, Oliveira AL. 2020. Determination of functional compounds in blue shark (Prionace glauca) liver oil obtained by green technology. Grasas Aceites $\mathbf{7 1}(2)$, e354. https://doi.org/10.3989/gya.0450191

Copyright: (C2020 CSIC. This is an open-access article distributed under the terms of the Creative Commons Attribution 4.0 International (CC BY 4.0) License. 


\section{INTRODUCTION}

The blue shark belongs to the Chondrichthyes class, Elasmobranchii subclass, and Carcharhinidae family of approximately 465 species with varied characteristics. There are considerable differences between sharks and other fish, such as in their cartilaginous skeleton and maintenance of osmotic equilibrium in the presence of urea and trimethylamine oxide in their blood and tissues (Tenuta-Filho and Macedo, 2015; Pacheco and Barrera-Arellano, 1994; Vögler et al., 2012). Their liver oil contains between 10 to $20 \%$ squalene, as well as large concentrations of triacylglycerols and vitamin A (Bartfai et al., 2000).

The blue shark (Prionace glauca) can be found in tropical and temperate waters around the world and is probably the most abundant of all sharks. Its distribution in the Atlantic Ocean spans from North America to Argentina in the west, and from Norway to South Africa in the east (Bornatowski and Schwingel, 2008; Tavares et al., 2012). It is mainly caught through secondary fishing by long lines and gill nets in fisheries aiming for tuna and swordfish (Vázquez et al., 2016).

Fishing of this species is expanding, and it was one of the most commonly-fished species in Europe in 2013, totaling more than 8,600 tons marketed as fresh and frozen fish, which are commonly processed as loins, filets, or steaks (Alves et al., 2016; Vázquez et al., 2016). In many countries, blue shark meat is consumed fresh, smoked, or salted; the skin is used for leather products; the fins are used for shark fin soup; and liver oil and fish flour are also produced (Abreu et al., 2011).

Blue shark liver oil is considered useful in the treatment of diseases resulting from impaired immune response and in the adjuvant treatment of several cancer types. In addition, the consumption of liver oil normalizes the activity of defense cells, improves neutrophil response to bacteria, and increases the total antioxidant capacity of the serum, among other effects. (Anschau and Iagher, 2011; Gironi and Maschietti, 2006; Hajimoradi et al., 2009). These and other applications are related to the oil's composition, which is largely formed by polyunsaturated fatty acids and molecules such as squalene, alkylglycerols, and fat-soluble vitamins.

The polyunsaturated fatty acids omegas 3 and 6 also presented significant values for the majority of blue shark oils. Even so, the levels of DHA (docosahexaenoic acid) are remarkably high for all oils. Together with EPA (eicosapentaenoic acid), DHA are well known for preventing atherosclerosis, reducing blood pressure, and reducing triglyceride levels (García et al., 2006). Shapiro (2013) also mentions effects such as attenuation of different types of pain, reduction in post-myocardial infarction mortality, and inhibition of pro-inflammatory molecules, among others.
The isolation of functional components from diverse matrices is conventionally accomplished using various separation techniques, such as dual maceration, digestion, and percolation. For example, the commercial production of fish oil includes the mechanical pressing of tissues, followed by conventional extraction with an organic solvent (Lisichkov et al., 2014). Although widely applied, conventional extraction methods present problems, due to the toxicity or flammability of the solvents and the possibility of causing adverse health effects. They may also lead to the decomposition of thermolabile compounds like polyunsaturated fatty acids when high temperatures are employed during processing (Gedi et al., 2015; Ivanovs and Blumberga, 2017).

The supercritical fluid extraction (SFE) method is a promising green technology that offers several advantages over conventional methods, such as high compressibility, liquid-like density, low viscosity, and high diffusivity (Kang et al., 2017). Moreover, extraction with supercritical carbon dioxide offers new opportunities for solving separation problems, as it presents low toxicity. In addition, it is considered a non-flammable solvent, cheap, clean, and the solvation capacity of the $\mathrm{CO}_{2}$ in the supercritical phase can be controlled through the manipulation of pressure and/or temperature, providing adequate selectivity and preventing the co-extraction of polar impurities, such as some inorganic derivatives with heavy metals (Ahmed et al., 2017; Haq et al., 2017).

The objectives of this research were to obtain and characterize blue shark liver oils obtained by supercritical technology with respect to their physical and chemical parameters, as well as the presence of compounds of interest for the food and pharmaceutical industries.

\section{MATERIALS AND METHODS}

\subsection{Extraction and characterization of blue shark liver oil}

Blue sharks were fished by the company Oceanus Comércio e Transporte LTDA, located at the Recife Port (PE), Brazil. Animals over $1 \mathrm{~m}$ in length were collected by the fishermen using the long-line method during the 15 days of the vessel's stay at sea, in the Exclusive Economic Zone (EEZ) of Brazil, and were kept refrigerated during the fishing period. The livers were collected when the boats docked at the port and were quickly packed in an ice box, where they were kept until transportation to the laboratory. This project was appropriately registered at IBAMA (39707-1 for SISBIO).

In the laboratory, the bile vesicles were separated from the livers, which were frozen, filleted, and dried in a lyophilizer (Liotop LP1040, Liobrás, São Carlos, SP, Brazil) for 24 hours. After drying, the livers were vacuum packed in a laminated package 
(two pieces of liver in each) in order to eliminate oxygen and avoid contact with light, thus preserving samples for as long as possible without drastic alterations in composition.

An aliquot of the samples was used to analyze the centesimal composition, according to the norms determined by the Adolfo Lutz Institute (Zenebon et al., 2008). Moisture (method 012/IV), ash (method 018/IV), lipid (method 032/IV), fiber (method 044/IV), and protein (method 036/IV) contents were determined in triplicate, and, subsequently, the carbohydrate assays were calculated using the differences.

The commercial shark liver oil (CSLO) $\left(\right.$ Ecomer $^{\circledR}$ São Paulo, SP, Brazil) was purchased and used as a control in this research. It was kept packed in capsules of pharmaceutical gelatin, glycerin, and water in a closed container until the moment of the tests.

\subsection{Supercritical extraction of the blue shark liver oil}

At the time of extraction, the lyophilized livers were cut into small pieces (approximately $1 \mathrm{~cm}^{3}$ ) and packed $(15 \mathrm{~g})$ into a fixed bed of $300 \mathrm{~cm}^{3}$, also filled with glass beads. The properly fitted fixed bed was set in the extractor at the time of extraction. The supercritical extractor (Thar SFC, Pittsburgh, United States) provided fine control for pressure, temperature, and $\mathrm{CO}_{2}$ flow using equipment software (Thar Technologies Inc., SuperChrom SFC Suite v. 5.9, Pittsburgh, Pennsylvania, United States).

The extraction begain with the cooling (Thermo Scientific, Walthan, Massachusetts, USA) and compression (Thar P54, Pittsburgh, USA) of $\mathrm{CO}_{2}$ (99.5\%, Oxinitro, Pirassununga, Brazil) of the fixed bed. Inside the jacketed extractor, the system reached working pressure and temperature and the $\mathrm{CO}_{2}$ flow was maintained as defined. The extractions were carried out for $6 \mathrm{~h}$ using a constant flow of $8 \mathrm{~g} \mathrm{CO}_{2} / \mathrm{min}$. For this work, a statistical strategy was used with 3 replicates and a $5 \times 2$ factorial design, covering 5 pressures and 2 temperatures, totaling 30 trials (Table 2). The choice of pressures and temperatures was made based on a study on cobia liver published by this research group (Santos et al., 2016).

The oil yields obtained under the different operating conditions were calculated in two ways. First, the mass balance was calculated by the mass ratio, being the ratio between the initial mass of liver packed in the fixed bed and the final mass after extraction, called overall yield (OY) (eq. (1)). Second, the extraction yield (EY) was obtained from the ratio between the oil mass collected in the flask at the end of the extraction and the initial mass of liver packed inside the extractor (eq. (2)).

$$
\mathrm{OY}(\%)=\frac{\left(\mathrm{LM}_{\mathrm{i}}-\mathrm{LM}_{\mathrm{f}}\right)}{\mathrm{LM}_{\mathrm{i}}} \times 100
$$

where:

$\mathrm{LM}_{\mathrm{i}}$ - initial liver mass;

$\mathrm{LM}_{\mathrm{f}}$ - final liver mass (at the end of extraction)

$\mathrm{EY}(\%)=\frac{\left(\mathrm{M}_{\text {oil }}\right)}{\mathrm{LM}_{\mathrm{i}}} \times 100$

where:

$\mathrm{M}_{\text {oil }}$ - oil mass extracted;

$\mathrm{LM}_{\mathrm{i}}$ - initial liver mass.

The morphology of the blue shark liver samples as well as the possible changes occurring after contact with $\mathrm{CO}_{2}$ under supercritical conditions were visualized with scanning electron microscopy (SEM). The samples were separated before and after extraction and fixed with double-sided carbon tape on an aluminum support. Subsequently, SEM micrographs with $5 \mathrm{kV}$ acceleration voltage were generated (Hitachi, TM 3000, Tokyo, Japan), using varying magnifications.

\subsection{Oil characterization}

\subsubsection{Physicochemical analyses}

The refractive index (RI) of the oil samples was measured in a refractometer (LAMBDA 2WAJ, ATTO Instruments Co, Tsuen Wan, Hong Kong) as a function of sodium light at $589.3 \mathrm{~nm}$ wavelength and at the temperatures of $25^{\circ} \mathrm{C}$ and $40{ }^{\circ} \mathrm{C}$. The calibration of the refractometer was performed with distilled water, whose refractive index is 1.3330 at $20^{\circ} \mathrm{C}$ (Zenebon et al., 2008). The oil density analysis was performed in a digital benchtop densimeter (DMA 4500, Anton Paar, Graz, Austria). The oil was injected with a syringe directly into the apparatus, and the density readings were performed at 25 and $40{ }^{\circ} \mathrm{C}$ in triplicate after the stabilization of each temperature.

The determination of the oil samples' viscosity, also performed at the same temperatures as the density analysis, was made using the AMVn Automated Microviscometer (Anton Paar, Graz, Austria). The samples were placed in a $1.8 \mathrm{~mm}$ calibrated glass capillary tube. The capillary tube was coupled to the apparatus, and the readings were performed in quadruplicate at each temperature under three different angles of displacement $\left(50,60\right.$, and $\left.70^{\circ} \mathrm{C}\right)$, totaling 12 measurements per sample.

To determine the acid value (as oleic acid) (AI), a titration method was used based on the previous solubilization of the sample with ethyl ether (Ecibra, São Paulo, SP, Brazil): alcohol (Panreac Química S.A.U., Barcelona, Spain) 2:1 and then titration with a standard solution of $0.01 \mathrm{M}$ sodium hydroxide (Haloquímica, São Paulo, SP, Brazil) with phenolphthalein (Synth, Diadema, SP, Brazil) to determine the turning point (method 325/IV of Zenebon et al., 2008). For the determination of the peroxide value $(\mathrm{PI})$, the titration method was used, where 
the samples were mixed with acetic acid (Synth São Paulo, Brazil), chloroform (Êxodo, São Paulo, Brazil), potassium iodide (Synth, São Paulo, Brazil), distilled and titrated water with a standard solution of sodium thiosulphate (Haloquímica, São Paulo, Brasil), and starch (Haloquímica, São Paulo, Brasil) as indicator (method 326/IV of Zenebon et al., 2008).

For the determination of the iodine value (IO), the oil samples were mixed with cyclohexane (Synth, São Paulo, Brazil) and a Wijs solution (Haloquímica, São Paulo, Brazil), potassium iodide, and distilled water. Titration was performed with a standard solution of sodium thiosulfate with a starch solution as indicator (method 329/IV of Zenebon et al., 2008). The saponification value (SV) was determined by mixing the sample with a potassium hydroxide solution (Exodo, São Paulo, Brazil) and phenolphthalein and, then, titration with hydrochloric acid (Haloquímica, São Paulo, Brazil, method 328/IV of Zenebon et al., 2008).

\subsubsection{Quantification of fatty acids}

The fatty acid profile was performed according to AOAC 2005 (Method 991.39) with modifications. $50 \mathrm{mg}$ of sample were mixed with a $0.5 \mathrm{M}$ methanolic $\mathrm{NaOH}$ solution (Synth, Diadema, S, Brazil) and heated in a water bath at $100^{\circ} \mathrm{C}$ for $5 \mathrm{~min}$. Methanolic BF3 (Sigma-Aldrich, Saint Louis, MO, USA) was added, and the mixture was heated again for $30 \mathrm{~min}$. Then, $10 \mathrm{~mL}$ of saline solution and $1 \mathrm{~mL}$ of hexane (Merck, Darmstadt, Germany) were added, and the mixture was stirred. The supernatent containing fatty acid methyl esters was collected and dried. The samples were diluted in hexane for injection into the chromatograph.

Injection $(1 \mu \mathrm{L})$ analysis of the fatty acids was done using gas chromatography coupled with a mass spectrometer (QP 2010 Plus, Shimadzu, Tokyo, Japan) using an automatic injector (AOC-5000, Shimadzu, Tokyo, Japan). A capillary column with bis-cyanopropyl polysiloxane stationary phase $(100 \mathrm{~m} \times 0.25 \mathrm{~mm}$ id $\times 0.20 \mu \mathrm{m}$ df, SP-2560 Supelco, Bellefonte, USA) and Helium gas at $19.5 \mathrm{~cm} / \mathrm{s}$ were used. The temperature of the injector was $250^{\circ} \mathrm{C}$ and the detector temperature was $260^{\circ} \mathrm{C}$. The temperature of the oven was set so as to obtain a gradient, starting at $100^{\circ} \mathrm{C}$ for $1 \mathrm{~min}$, at $100^{\circ} \mathrm{C}$ to $195^{\circ} \mathrm{C}$ at a rate of $5^{\circ} \mathrm{C} / \mathrm{min}$ and then $195^{\circ} \mathrm{C}$ to $250^{\circ} \mathrm{C}$. The prior identification of the peaks was done by comparing the mass spectra of the NIST and NIST 08 libraries; and the quantification was done by external normalization, relating the area of the peaks to the standard curve of methyl meristat (SigmaAldrich, Sant Louis, USA). These conditions were based on AOAC methodology (method 996.05, 2005).

\subsubsection{Quantification of squalene and vitamin A}

The quantification of squalene was performed following the methodology of the study by Lu et al.,
(2003), where $0.5 \mathrm{~g}$ of oil was mixed with $40 \mathrm{ml}$ of a methanol-acetone solution $(7: 3, \mathrm{v} / \mathrm{v})$. After homogenization (IKA, VG 3 S000, Washington, USA) the mixture was stored at $-2{ }^{\circ} \mathrm{C}$ for $30 \mathrm{~h}$, and the supernatant was filtered with a $0.45 \mathrm{~mm}$ membrane (Whaltman, Kent, UK). The residue was washed once with $5 \mathrm{~mL}$ of a cooled methanol-acetone solution $(7: 3, v / v)$ at $-20^{\circ} \mathrm{C}$. The filtrate was dried and resuspended in $5 \mathrm{~mL}$ of acetone prior to the injection.

The conditions of the chromatographic analysis were based on the research by Brunner et al., (2009) with minimal modifications. A 5\% diphenyl/95\% dimethylpolysiloxane RTX-5MS column $(30 \mathrm{~m} \times$ $0.25 \mathrm{~mm}$ i.d. $\times 0.20 \mu \mathrm{m}$ d.f.; Restek, Bellefonte, USA) and helium gas at $19.5 \mathrm{~cm} / \mathrm{sec}$ were used as the stationary phase. $1.0 \mu \mathrm{L}$ of the filtrate was injected in the splitless mode, and the temperatures of the injector, detector, and interface were 280,300, and $300{ }^{\circ} \mathrm{C}$, respectively. The heating gradient started at $130{ }^{\circ} \mathrm{C}$ for $2 \mathrm{~min}, 130{ }^{\circ} \mathrm{C}$ to $200^{\circ} \mathrm{C}$ at a rate of $10{ }^{\circ} \mathrm{C} / \mathrm{min}, 200^{\circ} \mathrm{C}$ to $290^{\circ} \mathrm{C}$ at $5^{\circ} \mathrm{C} / \mathrm{min}$ and held at $290^{\circ} \mathrm{C}$ for $15 \mathrm{~min}$. Peak identification was done via comparison of the mass spectra with the software database and also by comparing the retention time of the analyte with the standard, which was analyzed under the same conditions. Quantification was done using external normalization with concentrations of squalene (Santa Cruz, Dallas, United States).

The determination of vitamin A was performed according to the European Pharmacopoeia methodology (2004) with some modifications. $3 \mathrm{~mL}$ of potassium hydroxide solution (50\% in distilled water) and $30 \mathrm{~mL}$ of ethanol were added to $1.0 \mathrm{~g}$ of oil. The mixture remained heated for $30 \mathrm{~min}$ and was then cooled. After being transferred to the decantation flask, $30 \mathrm{~mL}$ of distilled water were added. Afterwards, the system was washed three times with $50 \mathrm{~mL}$ of ethyl ether. The supernatent was washed four times with $50 \mathrm{~mL}$ of distilled water. The fraction of ethyl ether containing vitamin A (all-trans-retinol) was dried in nitrogen, and the dry fraction was re-suspended in isopropanol (Synth, São Paulo, Brazil) at a concentration of $500 \mathrm{ppm}$. The solution was submitted to a spectrophotometer reading (FEMTO, Cirrus 80ST, São Paulo, Brazil) at $325 \mathrm{~nm}$. A retinol equivalent (RE), eq. (3) was used for the calculation of vitamin A content.

$$
\text { Vit. } \mathrm{A}(\mathrm{RE} \mathrm{p} / \mathrm{gram})=\underset{0.30}{\left(\mathrm{~A}_{-} 325 \times 1830 / 100 \mathrm{~m} \times \mathrm{V}\right) \times}
$$

where:

A325 = absorbance at $325 \mathrm{~nm}$;

$\mathrm{M}=$ sample mass (grams);

$\mathrm{V}=$ total volume of the solution containing

10-15 U.I. of vitamin A per $\mathrm{mL}$;

$1830=$ conversion factor for the all-trans-retinol specific absorbance (U.I).

The results of this work are expressed as mean \pm standard deviation. The averages of the results 
were statistically evaluated by one-way and twoway ANOVA using a Tukey post-hoc test, at a 95\% significance level to detect significant differences in responses among the different treatments. Pearson's correlation analyses $(p<0.05)$ were performed among the levels of squalene and $\mathrm{CO}_{2}$ densities for each supercritical extraction.

\section{RESULTS AND DISCUSSION}

\subsection{Characterization of blue shark liver and extraction yield of oils}

The centesimal composition of the blue shark liver (Table 1) highlights the large amount of lipids, reaching almost $80 \%$ on a dry basis. This high percentage can be attributed to the low humidity (only $2 \%$ ), due to the efficient lyophilization of the sample. After lipids, proteins make up a major part of the composition.

The protein matrix of high biological value, such as the shark liver protein, after being subjected to oil extraction using supercritical $\mathrm{CO}_{2}$, can be employed as a source of protein in different processes. Among these, the enzymatic hydrolysis of these proteins for the recovery of compounds with biological activity can be noted. Enzymatic hydrolysis is considered to be a convenient method for the production of compounds that can be used in the pharmaceutical and nutraceutical fields, where various hydrolyzates of fish proteins have shown potential antioxidant, antihypertensive, antithrombotic, and antimicrobial effects (García-Moreno et al., 2014).

The results of the blue shark liver oil extractions were calculated using two equations (eq. (1) and eq. (2)). The difference between the results treated by the overall yield and the extraction yield (Table 2) results from the fraction of oil lost in the equipment line which is collected during the de-pressurizing of the system. For some conditions, it was verified that a

TABLE 1. Operational conditions of $\mathrm{P}$ and $\mathrm{T}$ used in the supercritical fluid extraction (SFE) of blue shark liver oil

\begin{tabular}{lcc}
\hline Essay & $\mathbf{P}(\mathbf{b a r})$ & $\mathbf{T}\left({ }^{\circ} \mathbf{C}\right)$ \\
\hline 1 & 100 & 50 \\
2 & & 60 \\
3 & 150 & 50 \\
4 & & 60 \\
5 & 200 & 50 \\
6 & & 60 \\
7 & 250 & 50 \\
8 & & 60 \\
9 & 300 & 50 \\
10 & & 60 \\
\hline
\end{tabular}

$\mathrm{P}$ is pressure, $\mathrm{T}$ is temperature. certain amount of oil also adhered to the glass beads that filled the fixed bed. Consequently, under these conditions of lower pressures (100 and 150 bar), the extraction yield was low, as in tests 1 and 2, for example, indicating lower solubilization of the oil by supercritical $\mathrm{CO}_{2}$. As expected, the OY was higher than the EY for all assays (Table 2).

At lower pressures, lower solubilization was observed because SFE extraction combines two different steps: firstly the compression of the raw material, which results in the oil coming out of the cellular structure, followed by the solubilization of the oil in the supercritical $\mathrm{CO}_{2}$, which allows the extract to flow out of the extraction vessel. Indeed, at low pressures, the second step does not take place (due to low oil solubility) and the oil is not dissolved in the supercritical $\mathrm{CO}_{2}$ and does not flow out of the extraction vessel. To overcome with this obstacle, the glass beads could have been washed with solvent and after removing the solvent the amount of oil could be quantified. But the use of organic solvents was not the aim of this work.

For the different $\mathrm{P}$ and $\mathrm{T}$ conditions applied, yield values ranged from 0 to $60.02 \%$ (Table 2). The means test showed that the yields obtained for different $\mathrm{T}$ at the same pressure were statistically equal. When operating pressures were increased, yields also increased. High pressures contribute to a higher density of $\mathrm{CO}_{2}$, which gives it a higher solvency power. Therefore, the solute vapor pressure had a lower solubilization influence than the solvent density for the two T values studied. Moreover, the distance between the molecules decreased and the interaction between the oil and $\mathrm{CO}_{2}$ intensified with increasing density, leading to greater solubility of the oil in the supercritical solvent (Sahena et al., 2010). Assuming that the maximum oil contained in this starting material was $80 \%$ (Table 1), SFE yielded $60 \%$ yield at its best condition during 6 hours of extraction, which implies the extraction of $75 \%$ of the oil.

The blue shark liver structure was also analyzed before and after supercritical extraction. All blue shark liver samples submitted to SFE presented structural modifications (Fig 1). Although there

TABLE 2. Centesimal composition of blue shark liver ${ }^{\mathrm{a}}$

\begin{tabular}{lc}
\hline Moisture & $2.1 \pm 0.6$ \\
Ashes & $1.2 \pm 0.1$ \\
Protein & $20.2 \pm 0.3$ \\
Fibers & $0.29 \pm 0.04$ \\
Lipid & $76.20 \pm 3.80$ \\
Carbohydrates & $\mathrm{nd}^{\mathrm{b}}$ \\
\hline
\end{tabular}

${ }^{\mathrm{a}}$ All measurements are expressed in $\mathrm{g} / 100 \mathrm{~g}$ of sample on dry basis.

bnd - not detected. 


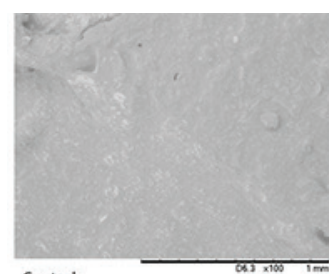

Control
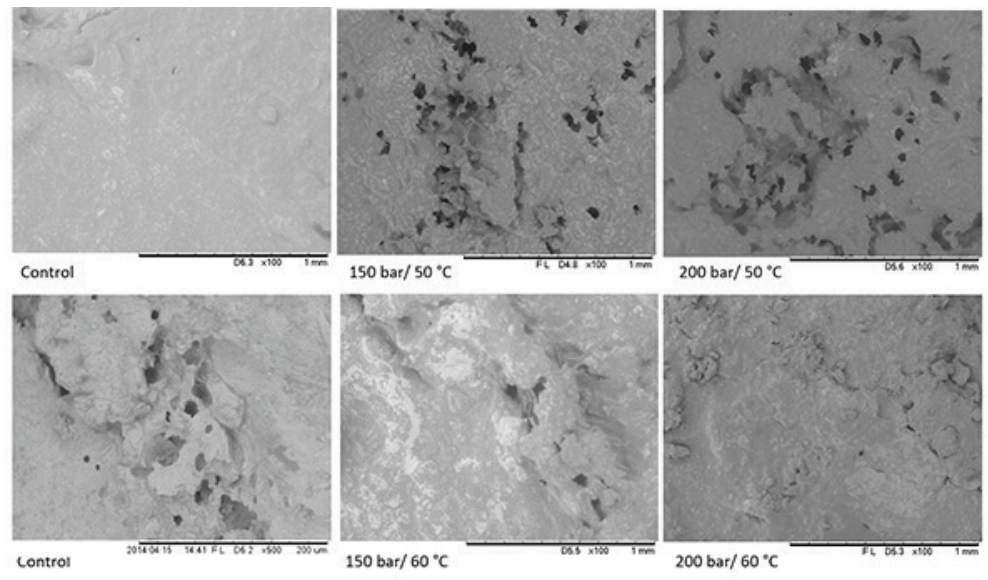

$200 \mathrm{bar} / 50^{\circ} \mathrm{C}$

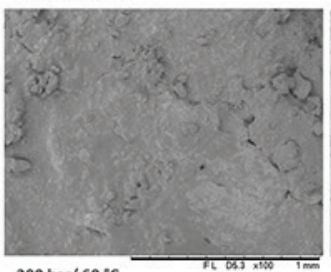

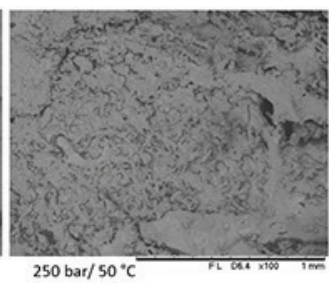
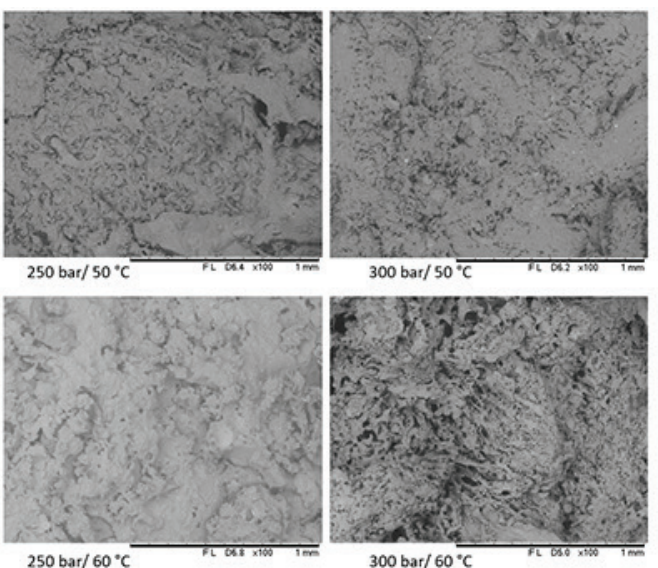

300 bar $/ 50^{\circ} \mathrm{C}$

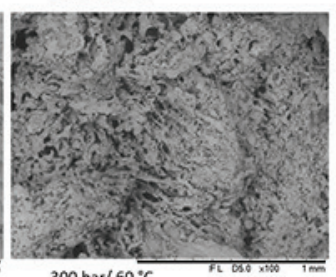

FIGURE 1. Micrographs of blue shark liver samples submitted to SFE and control sample, without extraction.

was no correlation between the increase in pressure applied during extraction and the degree of tissue rupture, these factors can be correlated through this physical analysis. In other words, as the fluid applied in the extraction became moredense, greater modifications were observed in the matrix. In the study by Taher et al., (2014), it was found that the lyophilization process made the matrix (a cellular microalgae biomass) more porous and that this structural change increased the dissolution of the lipids in the supercritical fluid, contributing to a higher extraction yield. Thus, although no lyophilized or non-lyophilized matrix comparisons were made in this work, it can be inferred from the literature and applied to the blue shark liver oil extraction process. A high extraction yield and the formation of pores in the raw material (Fig. 1) were also verified after the lyophilization process was used.

\subsection{Characterization of blue shark oil}

The physicochemical characterization of OFCA samples is presented in Tables 3 and 4 . The results for the different oils analyzed are statistically close to each other, except for the refractive index values at $25^{\circ} \mathrm{C}$. Most of the parameters were similar to those found in the commercial shark liver oil sample. The only exception was viscosity, which was higher for the refined oil.

Even so, supercritical extraction without further purification steps generated oils with physicochemical patterns similar to industrially processed oils. This makes this process of obtaining oils advantageous, since subsequent purification steps, as indicated in the interpretation of these data, may not be necessary.

As expected, density $(\rho)$ and dynamic viscosity $(\eta)$ values decreased in relation to the increase

TABLE 3. Yields of supercritical fluid extraction of blue shark liver oil (Prionace glauca)

\begin{tabular}{lccccc}
\hline Essay & $\mathbf{P}(\mathbf{b a r})$ & $\mathbf{T}\left({ }^{\circ} \mathbf{C}\right)$ & $\boldsymbol{\rho} \mathbf{C O}_{2}\left(\mathbf{K g} / \mathbf{m}^{3}\right)$ & $\mathbf{O Y ~}(\%)^{*}$ & $\mathbf{E Y ~}(\%)^{* * *}$ \\
\hline 1 & 100 & 50 & 390.97 & $13.95 \pm 2.12^{\mathrm{de}}$ & $0.007 \pm 0.010^{\mathrm{d}}$ \\
2 & 100 & 60 & 291.55 & $22.30 \pm 4.12^{\mathrm{d}}$ & $0.02 \pm 0.01^{\mathrm{d}}$ \\
3 & 150 & 50 & 702.30 & $17.15 \pm 2.47^{\mathrm{d}}$ & $6.88 \pm 0.49^{\mathrm{d}}$ \\
4 & 150 & 60 & 607.22 & $5.22 \pm 5.08^{\mathrm{e}}$ & $1.32 \pm 0.57^{\mathrm{d}}$ \\
5 & 200 & 50 & 785.91 & $34.00 \pm 0.93^{\mathrm{c}}$ & $22.55 \pm 0.82^{\mathrm{c}}$ \\
6 & 200 & 60 & 725.32 & $24.44 \pm 2.65^{\mathrm{cd}}$ & $15.29 \pm 1.33^{\mathrm{c}}$ \\
7 & 250 & 50 & 835.32 & $52.14 \pm 3.48^{\mathrm{b}}$ & $44.07 \pm 2.83^{\mathrm{b}}$ \\
8 & 250 & 60 & 787.57 & $49.76 \pm 3.81^{\mathrm{b}}$ & $36.59 \pm 2.32^{\mathrm{b}}$ \\
9 & 300 & 50 & 871.24 & $71.10 \pm 1.33^{\mathrm{a}}$ & $60.02 \pm 1.25^{\mathrm{a}}$ \\
10 & 300 & 60 & 830.41 & $65.47 \pm 5.17^{\mathrm{a}}$ & $52.34 \pm 6.49^{\mathrm{a}}$ \\
\hline
\end{tabular}

$\mathrm{P}$ is Pressure, $\mathrm{T}$ is Temperature, $\mathrm{\rho CO}_{2}$ is carbon dioxide density, $\mathrm{OY}$ is overall yield and $\mathrm{EY}$ is extraction yield.

Percentages of oils followed by equal letters in the same column did not differ statistically at the $95 \%$ level of significance by Tukey's mean test. 
TABLE 4. Physical-chemical parameters of blue shark liver oil obtained via SFE

\begin{tabular}{|c|c|c|c|c|c|c|c|c|}
\hline Essay & $\mathbf{P}$ (bar) & $\mathrm{T}\left({ }^{\circ} \mathrm{C}\right)$ & $\begin{array}{c}\rho\left(25^{\circ} \mathrm{C}\right) \\
(\mathrm{g} / \mathrm{mL})\end{array}$ & $\begin{array}{c}\rho\left(40^{\circ} \mathrm{C}\right) \\
(\mathrm{g} / \mathrm{mL})\end{array}$ & $\begin{array}{c}\eta\left(25^{\circ} \mathrm{C}\right) \\
(\mathrm{Pa} \times \mathrm{s})\end{array}$ & $\begin{array}{c}\eta\left(40^{\circ} \mathrm{C}\right) \\
(\text { Pas } \times \mathrm{s})\end{array}$ & $\mathrm{RI}\left(25^{\circ} \mathrm{C}\right)$ & $\mathrm{RI}\left(40^{\circ} \mathrm{C}\right)$ \\
\hline 1 & 100 & 50 & nd & nd & nd & nd & nd & nd \\
\hline 2 & 100 & 60 & nd & nd & nd & nd & nd & nd \\
\hline 3 & 150 & 50 & nd & nd & nd & nd & nd & nd \\
\hline 4 & 150 & 60 & nd & nd & nd & nd & nd & nd \\
\hline 5 & 200 & 50 & $0.920 \pm 0.001^{\mathrm{a}}$ & $0.910 \pm 0.001^{\mathrm{a}}$ & $56.47 \pm 2.49^{\mathrm{a}}$ & $32.25 \pm 3.32^{\mathrm{a}}$ & $1.4765 \pm 0.0005^{\mathrm{ab}}$ & $1.4715 \pm 0.0005^{\mathrm{a}}$ \\
\hline 6 & 200 & 60 & $0.922 \pm 0.003^{\mathrm{a}}$ & $0.911 \pm 0.002^{\mathrm{a}}$ & $55.97 \pm 1.25^{\mathrm{a}}$ & $31.42 \pm 0.82^{\mathrm{a}}$ & $1.4760 \pm 0.0000^{\mathrm{b}}$ & $1.4718 \pm 0.0006^{\mathrm{a}}$ \\
\hline 7 & 250 & 50 & $0.921 \pm 0.000^{\mathrm{a}}$ & $0.910 \pm 0.000^{\mathrm{a}}$ & $53.47 \pm 0.41^{\mathrm{a}}$ & $29.89 \pm 1.08^{\mathrm{a}}$ & $1.4780 \pm 0.0005^{\mathrm{ab}}$ & $1.4728 \pm 0.0010^{\mathrm{a}}$ \\
\hline 8 & 250 & 60 & $0.920 \pm 0.001^{\mathrm{a}}$ & $0.909 \pm 0.001^{\mathrm{a}}$ & $53.87 \pm 0.88^{\mathrm{a}}$ & $30.58 \pm 0.44^{\mathrm{a}}$ & $1.4775 \pm 0.0013^{\mathrm{ab}}$ & $1.4723 \pm 0.0008^{\mathrm{a}}$ \\
\hline 9 & 300 & 50 & $0.920 \pm 0.001^{\mathrm{a}}$ & $0.910 \pm 0.001^{\mathrm{a}}$ & $52,55 \pm 1.38^{\mathrm{a}}$ & $29.17 \pm 0.38^{\mathrm{a}}$ & $1.4780 \pm 0.0008^{\mathrm{ab}}$ & $1.4728 \pm 0.0013^{\mathrm{a}}$ \\
\hline 10 & 300 & 60 & $0.920 \pm 0.000^{\mathrm{a}}$ & $0.910 \pm 0.000^{\mathrm{a}}$ & $52.82 \pm 2.30^{\mathrm{a}}$ & $30.21 \pm 1.35^{\mathrm{a}}$ & $1.4785 \pm 0.0005^{\mathrm{a}}$ & $1.4727 \pm 0.0008^{\mathrm{a}}$ \\
\hline CSLO & & & $0.908^{*} \pm 0.000$ & $0.894 \pm 0.000$ & $91.21 \pm 0.00$ & $39.27 \pm 0.00$ & $1.4715 \pm 0.0000$ & $1.4670 \pm 0.0000$ \\
\hline
\end{tabular}

nd - not detected; *Density and viscosity for the CSLO were measured at $20^{\circ} \mathrm{C}$; Refractive Index (RI) is dimensionless. Physicochemical parameters followed by equal letters in the same column did not differ statistically at the $95 \%$ level of significance by Tukey's mean test.

in temperature (Table 3 ). The decrease in density with temperature occured due to the higher kinetic energy of the molecules at higher temperatures, and consequently, an increase in the volume of the substance resulted in a decrease in density (Schaschke et al., 2013).

Viscosity is a property resulting from the attraction forces between molecules that are relatively close to each other. Thus, when the kinetic energy increases (due to the increase in temperature), the molecules tend to remain together for less time, making the intermolecular forces less effective and decreasing viscosity (Canciam, 2010). In addition to temperature, other factors affect the viscosity of oils, such as the molecular weight of the components present, the melting point, and degree of unsaturation of the lipids present in the sample (Igwe, 2004).

The density values at $25^{\circ} \mathrm{C}$ found for the OFCA were within the range determined by Firestone (2006) for shark liver oil, ranging from 0.917 to 0.923 $\mathrm{g} \cdot \mathrm{mL}^{-1}$. They were also within the range imposed by the Brazilian legislation which regulates the standards of identity and quality ratio for shark liver oil as a nutritional complement (BRASIL, 1995), which indicates a range from 0.908 to $0.927 \mathrm{~g} \cdot \mathrm{mL}^{-1}$ for this oil at $25^{\circ} \mathrm{C}$.

Many shark liver oils contain several classes of low density lipids, notably squalene and diacylglycerol ethers (DAGE) (Magnusson and Haraldsson, 2011). Squalene (density $0.86 \mathrm{~g} \cdot \mathrm{mL}^{-1}$ ) and DAGE (density $0.89 \mathrm{~g} \cdot \mathrm{mL}^{-1}$ ) provide substantially more buoyancy capacity to the animal in the water per unit volume of triacylglycerol (TAG) (density $0.92 \mathrm{~g} \cdot \mathrm{mL}^{-1}$ ), which is the most common form of lipid storage in most animals (Wetherbee and Nichols, 2000). Thus, if the presence of these substances is linked to the decrease in oil density, this physical analysis of the oil obtained by supercritical fluid can give an indication of the presence of these compounds. This property may also indicate physicochemical adulterations, derived from the mixture of vegetable oils with oils of animal origin, for example, and, thus, constitutes an important characterization property of the sample.

The experimental values for the refractive index of the blue shark livers were similar to the values found in the study by Batista and Nunes (1992), using liver specimens from a Knifetooth dogfish (cação dente de faca) (1.472), velvet belly (1.475) and Portuguese dogfish (cação português) (1.472). The refractive indexes measured for blue-liver liver oil showed an average value of 1.4723 , similar to that found by Firestone (2006) for readings at $40^{\circ} \mathrm{C}$. Anvisa (BRASIL, 1995) established a refractive index at $40{ }^{\circ} \mathrm{C}$ ranging from 1.4704 to 1.4745 , which covered the measured values of the OFCA obtained via SFE.

Regarding acidity, saponification, and peroxide values, these generally indicate the qualitative state of the oil (Table 4). The acid value measures the amount of free fatty acids present in the sample. Although these are included among compounds naturally present in small amounts in oils because they may be the products of the hydrolytic degradation of triacylglycerols, their value is considered an important quality index for oils (Cho et al., 2013).

Blue shark liver oils obtained via SFE showed acidic levels (as oleic acid) between 1.1 and 2.2\%. 
Since the Brazilian legislation limits the acidity value (AV) to $2.8 \%$ of oleic acid for shark liver oil (BRASIL, 1995), the different oils obtained through SFE are in accordance with the current legislation. Samples of shark oils obtained by other extraction methods (Bligh and Dyer, Soxhlet and baking) had acid values of $4.8,6.3$, and $4.2 \%$, respectively (Sunarya et al., 1996), which are superior to the blue shark liver oils obtained in this research. This is another indication that the use of "clean" technology, such as SFE, is advantageous in obtaining oils with higher quality indexes, given that it does not use organic solvents or elevated temperatures in the extraction process.

The saponification value (SV) is defined as the amount of alkali required to saponify the fatty acids in a given mass of oil (Boran et al., 2006). Firestone (2006) and Anvisa (BRASIL, 1995) recommend values ranging from 170 and $190 \mathrm{mg} \mathrm{KOH} / \mathrm{g}$ of oil as acceptable saponification values for liver oil samples. In this case, in addition to the oil obtained in condition 6, the oil from condition 9 (300 bar and $50^{\circ} \mathrm{C}$ ) also presented this parameter above the allowed limit (Table 4).

Lipid oxidation is the main cause of deterioration, and the hydroperoxides formed by the reaction between oxygen and unsaturated fatty acids are the primary products of this reaction. Hydroperoxides are tasteless and odorless, but they rapidly react and form aldehydes, which have a strong and unpleasant taste and odor (O'Brien, 2004). Thus, as peroxides are unstable, their measurement is limited to the initial phases of lipid oxidation because the reactions continue to occur until the termination phase, which is the third stage of the oxidative process (Ferrari, 1998).

The peroxide content (PC) in blue shark liver oil ranged from 10 to 24 meq $\mathrm{O}_{2}$ active $/ \mathrm{kg}$ of oil. As it is a quality parameter involved in the lipid oxidation process, the acceptable limits are stringent. The European Food Safety Authority stipulates an interval of 3 to $20 \mathrm{meq} \mathrm{O}_{2}$ active $/ \mathrm{kg}$ of crude oil, without refining (EFSA, 2010). Using this range as the basis, once again only the oil obtained in condition 6 would be considered non-standard. The Codex Alimentarius is more rigorous, adopting a maximum value of up to 5 meq $\mathrm{O}_{2}$ active $/ \mathrm{kg}$ of oil (FAO, 2013). Considering this limit, all oils would be in disagreement.

The iodine value (IV) of the blue shark oils presented some significant differences. However, all these are considered low. In the study by Sunarya et al., (1996), the iodine value found for fish oil was 118 to $133 \mathrm{~g} \mathrm{I}_{2} / 100 \mathrm{~g}$ of oil.

The physicochemical stability attributed to the oils obtained by SFE when considering lipid degradation can be explained by the method itself. In the extraction process, the starting material must be dry, or in other words, it must have a low moisture content. The removal of water, considered a simple preparation stage for extraction, decreases the speed of the reactions that take place inside the matrix, including those related to oxidative processes (Gava, 2009).

Supercritical fluid extraction (SFE) has increasingly become an interesting technology for obtaining high quality fish oil from by-products. This approach employs moderate temperatures and provides an oxygen-free medium, which aims to reduce the oxidation of essential fatty acids during the extraction process. Additionally, it allows for the extraction of compounds selectively, such as low polarity lipids, while avoiding the co-extraction of polar impurities, such as heavy metals (Rubio-Rodriguez et al., 2012). The association of supercritical extraction with enzymatic and membrane separation processes is considered a suitable technology for the refining of fish oil, and many studies are pursuing the simplification of this method, which is limited by high costs (EFSA, 2010).

The fatty acid profile of the blue shark liver oil samples shows the diversity of the fatty acid methyl esters present. There were great differences among the fatty acid contents when different supercritical extraction conditions were used (Table 5). The mean values showed that the main fatty acids present in the samples were palmitic acid (C16:0) and oleic acid (C18:1). For blue shark samples collected in Southeastern Brazil, Pacheco and Barrera-Arellano (1994) also found C18:1 and C16:0 among the main fatty acids observed in their study. Additionally, they found $\mathrm{C} 22: 6$ (docosahexaenoic acid), which was also present in the blue shark oils in the present study.

The fatty acid profile of commercial shark liver oil, which served as reference for this study, showed lower amounts of most fatty acids when compared to oils obtained via SFE. Several factors may explain these reduced values, such as the refining process that the oil undergoes, which ultimately extends the shelf life of the oil, but decreases the amount of fatty acids present. Fournier et al., (2007) reported that the deodorization stage of fish oil, which involves thermal treatment, constitutes the most critical phase of the refining process. Long-chain polyunsaturated fatty acids are labile molecules that can be lost through different chemical transformations during the heat treatment, and these losses involve reactions of cyclization, polymerization, and geometric isomerization.

In addition, the oil used as the control has a large amount of squalene (almost 1\% of squalene, which will be discussed in section 3.3), as well as alkylglycerols or lipid ethers (manufacturer's information), which have been widely researched for their beneficial effects, such as antineoplastic and immune system stimuli effects (Fernández et al., 2013). However, these are not quantified by the traditional method for the determination of fatty acids. 
TABLE 5. Acidity, saponification, peroxide and iodine indices in shark blue liver oil obtained from SFE and commercial shark liver oil (CSLO)

\begin{tabular}{lcccccc}
\hline Essay & $\mathbf{P}(\mathbf{b a r})$ & $\mathbf{T}\left({ }^{\circ} \mathbf{C}\right)$ & AV & SV & PC & IV \\
\hline 1 & 100 & 50 & nd & nd & nd & nd \\
2 & 100 & 60 & nd & nd & nd & nd \\
3 & 150 & 50 & nd & nd & nd & nd \\
4 & 150 & 60 & nd & nd & nd & nd \\
5 & 200 & 50 & $1.76 \pm 0.00^{\mathrm{ab}}$ & $171.37 \pm 7.72^{\mathrm{cd}}$ & $17.49 \pm 8.11^{\mathrm{a}}$ & $135.47 \pm 6.96^{\mathrm{ab}}$ \\
6 & 200 & 60 & $2.22 \pm 0.13^{\mathrm{a}}$ & $556.03 \pm 12.09^{\mathrm{a}}$ & $24.04 \pm 1.18^{\mathrm{a}}$ & $128.61 \pm 2.76^{\mathrm{ab}}$ \\
7 & 250 & 50 & $1.27 \pm 0.15^{\mathrm{cd}}$ & $185.66 \pm 6.33^{\mathrm{bc}}$ & $14.94 \pm 2.89^{\mathrm{a}}$ & $149.21 \pm 20.15^{\mathrm{a}}$ \\
8 & 250 & 60 & $1.65 \pm 0.25^{\mathrm{bc}}$ & $177.92 \pm 7.33^{\mathrm{cd}}$ & $14.37 \pm 2.16^{\mathrm{a}}$ & $120.05 \pm 9.18^{\mathrm{b}}$ \\
9 & 300 & 50 & $1.13 \pm 0.08^{\mathrm{d}}$ & $206.54 \pm 8.18^{\mathrm{b}}$ & $16.06 \pm 2.57^{\mathrm{a}}$ & $128.48 \pm 5.10^{\mathrm{ab}}$ \\
10 & 300 & 60 & $1.60 \pm 0.31^{\mathrm{bcd}}$ & $190.19 \pm 9.07^{\mathrm{bc}}$ & $10.47 \pm 1.15^{\mathrm{a}}$ & $126.89 \pm 6.80^{\mathrm{ab}}$ \\
CSLO & & & $0.42 \pm 0.03^{\mathrm{e}}$ & $161.17 \pm 2.16^{\mathrm{d}}$ & $23.97 \pm 2.13^{\mathrm{a}}$ & $92.09 \pm 1.41^{\mathrm{c}}$ \\
\hline
\end{tabular}

Physico-chemical parameters followed by equal letters in the same column did not differ statistically at the $95 \%$ level of significance by Tukey's mean test; nd - not detected; AV is the acidity value in \% of oleic acid; SV is the saponification value in $\mathrm{mg} \mathrm{KOH} / \mathrm{g}$ oil; $\mathrm{PC}$ is the peroxide content in meq of $\mathrm{O}_{2}$ active/ $\mathrm{kg}$ oil; IV is the iodine value in $\mathrm{g} \mathrm{I}_{2} / 100 \mathrm{~g}$ oil.

In the commercial shark liver oil (CSLO) sample, the major fatty acids were oleic and palmitic acids, as found in the work of Firestone (2006). Even at low rates for most of the fatty acids analyzed, large amounts of omega-9 MUFAs, such as 8-eicosenoic, gondolic, erucic, and nervonic acids, were observed.

For all the oils evaluated, the group of fatty acids with the highest values was the monounsaturated class, presenting values ranging from 15.74 to $45.45 \mathrm{~g} / 100 \mathrm{~g}$ of oil. Considering the results presented by Corrềa et al., (2008), obtaining oils rich in unsaturated fatty acids was expected in the observed results. In their study on the fractionation of fish oil with $\mathrm{CO}_{2} \mathrm{SC}$, high separation factors were determined for short-chain fatty acids. These molecules tend to migrate to the lighter phase, rich in $\mathrm{CO}_{2}$, and to compounds with double bonds, evidencing the affinity of $\mathrm{CO}_{2}$ for unsaturation.

Unsaturated fatty acids are important components of cell membrane phospholipids with higher concentrations in the central nervous system. Physiologically, these fatty acids are essential for the healthy development of the brain and are of great importance for the maintenance of body homeostasis (Nemeth et al., 2014).

The levels of $\alpha$-linolenic and $\gamma$-linolenic acids were very low in the analyzed oil samples (Table 5), corresponding to less than $0.5 \%$ of the total area of the peaks of all the oil chromatograms (values not shown). In the study on blue shark liver oils by Jayasinghe et al., (2012), the values found for these fatty acids were also very low. Moreover, similar levels were found for oils from sharks fished from the Atlantic and the Pacific oceans (Kang et al., 1998).

\subsection{Quantification of squalene and vitamin A}

Blue shark liver oil contains squalene. The total ion chromatogram showed several peaks. The first set was identified as fatty acids (up to 20 min of running) and presented the peak for squalene at $32 \mathrm{~min}$ (Figure 2, Supplementary materials of this manuscript). Soon after squalene, the peak for cholesterol was observed, a molecule that shows structural similarity to squalene.

The extraction methodology for squalene was fractional crystallization, a method which brought the oil sample into contact with a defined proportion of methanol:acetone. According to Xu et al., (2005), fractional crystallization is known as the oldest separation method in the field of chemical engineering and is considered one of the best and cheapest methods available for the production of pure solids from impure solutions.

In the analysis of squalene, the triacylglycerols and other lipid-soluble and saponifiable components crystallized, which was not observed for squalene or other similar compounds that were solubilized in the solvent fraction and constituted the analytical fraction. As they are substances with very different retention times, they did not affect the analysis.

The levels of squalene varied significantly when different operating conditions were applied to the 


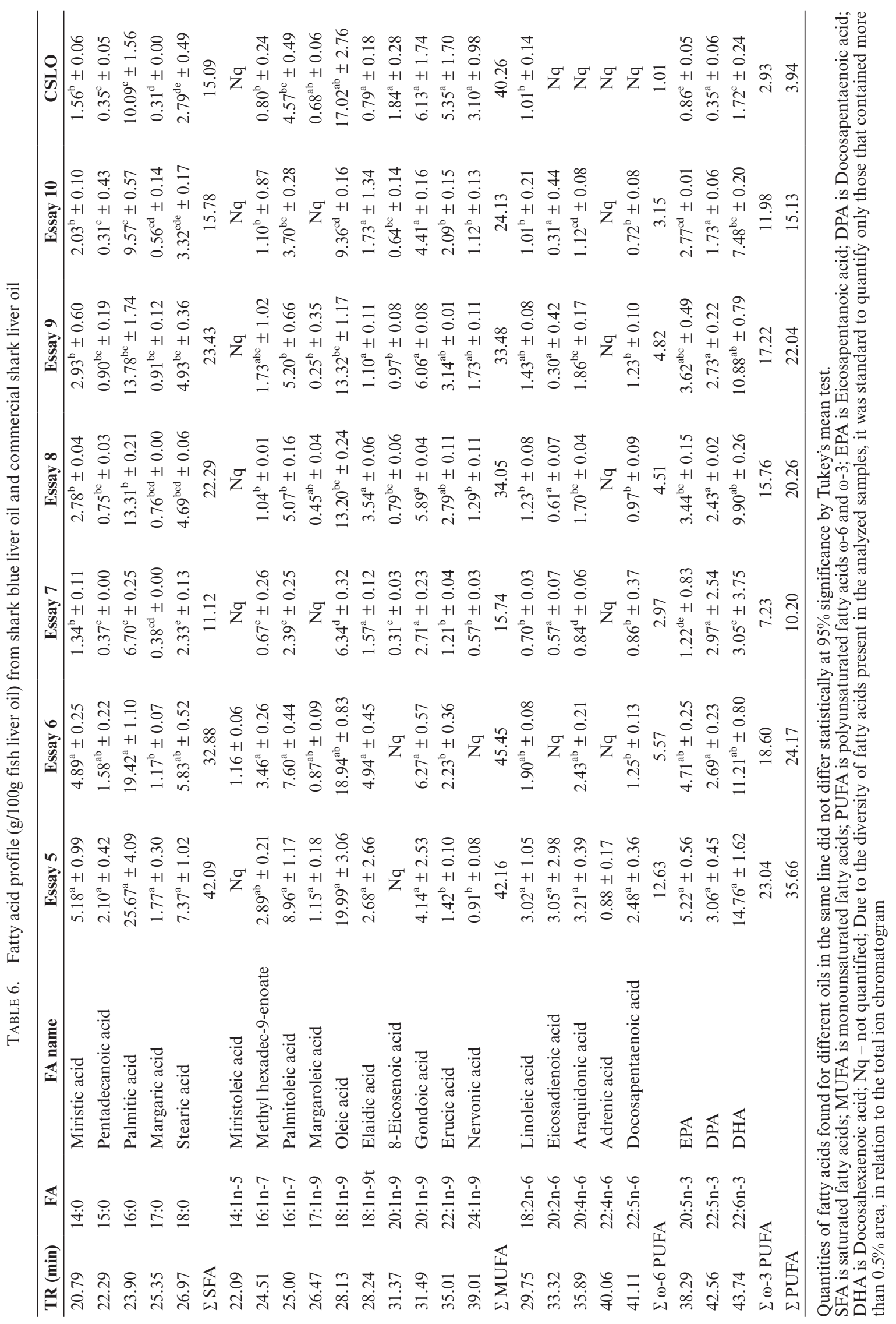



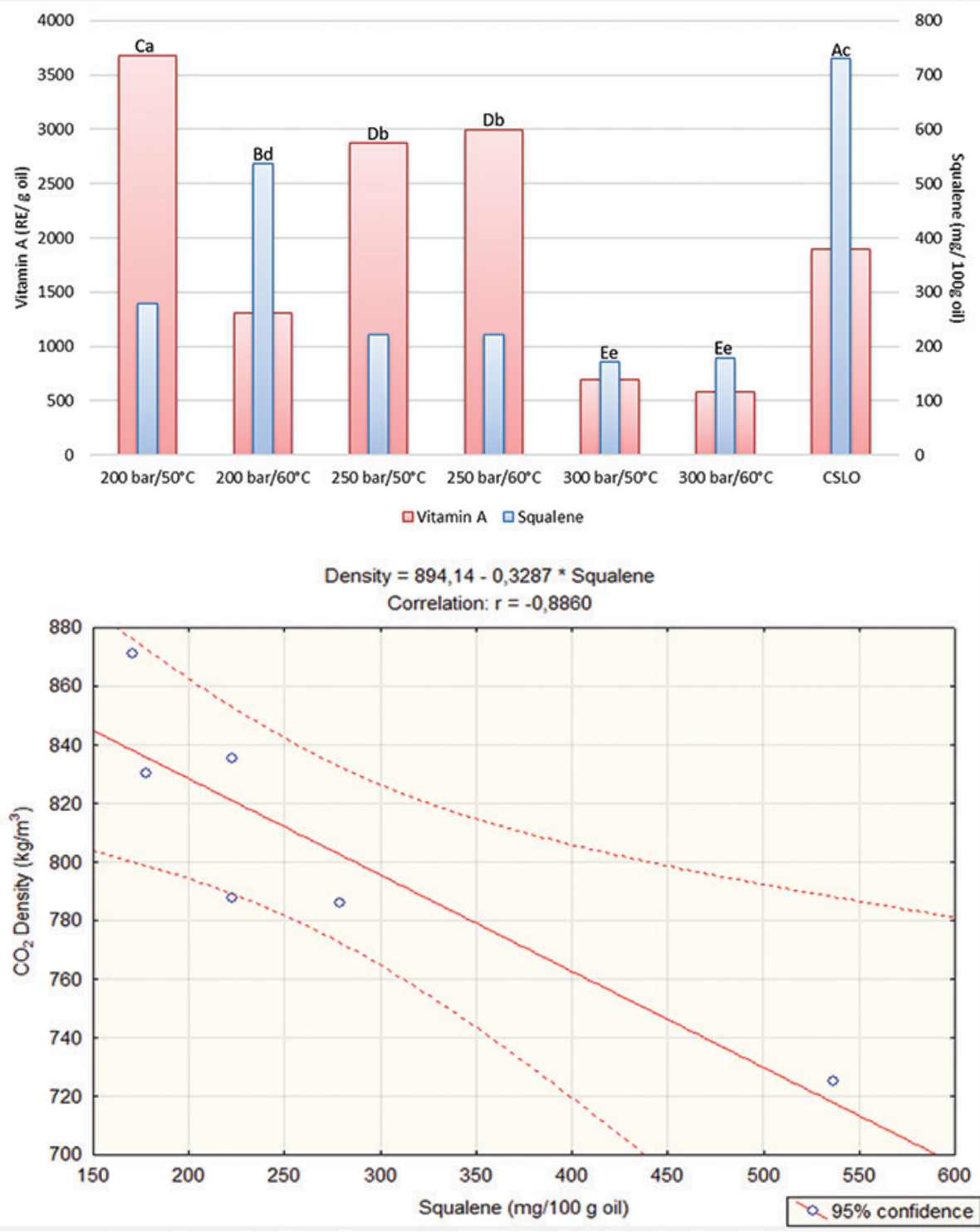

Figure 2. Vitamin A and squalene contents in commercial blue shark liver oils and oils obtained via SFE (2.1). Correlation between squalene content and $\mathrm{CO}_{2}$ applied to the SFE of blue shark liver oil (2.2). Different letters between bars (upper case for squalene and lowercase for vitamin A) show differences at the 0.05 level of the confidence limit according to the Tukey test.

supercritical extraction of blue shark oil (Figure 2.1, results in blue bars). Commercial shark liver oil had the highest squalene content $(730.91 \mathrm{mg} / 100 \mathrm{~g}$ of oil). Among the blue shark liver oils obtained with $\mathrm{CO}_{2} \mathrm{SC}$, the best results were observed when the lowest pressure conditions were applied, while the highest level was found at $200 \mathrm{bar} / 60{ }^{\circ} \mathrm{C}$, with $536.99 \mathrm{mg} / 100 \mathrm{~g}$ of oil.

The squalene content and the $\mathrm{CO}_{2}$ density applied to the extraction process resulted in a correlation coefficient of -0.88 ( $p<0.05$, Fig 2.2), which indicated that the highest levels of squalene were found when lower densities were applied to the supercritical oil extraction.
The opposite behavior was obtained in the research by Martinez-Correa et al., (2010), in which the solubility of pure squalene in $\mathrm{CO}_{2} \mathrm{SC}$ was studied. It is worth mentioning that, while these authors studied the solubility of a pure compound, squalene was obtained from a complex sample with triacylglycerols, fat-soluble vitamins, and other components that competed for solubilization and, therefore, may have interfered in the way this single compound was solubilized by $\mathrm{CO}_{2} \mathrm{SC}$.

The major sources of squalene are the sharks of the family Squalidae, in which the presence of the compound is considerable, and the results expressed in academic papers are presented in percentage in 
relation to the total oil. For example, the research of Hernández-Pérez et al., (2002) used samples of sea shark livers, where values of up to $50.5 \%$ squalene were verified in the oil. In the study by Bakes and Nichols (1995), the presence of squalene in the oils of several sharks reached about $82 \%$ (for the Centrophorus scalpratus species). For research using the same species as in this study, Prionace glauca, squalene was not found in its oil (Ballantyne, 1997).

Currently, the majority of these species containing large amounts of squalene are threatened by extinction. Once again, this research proves relevant, as it presents data of a shark species whose populations are not threatened, and their meat has increasing market demand and size. The residues of its processing, which are known to have great nutritional value and beneficial bioactive components, are not used, meaning that a great source of fish oil is currently being wasted.

There is a great amount of variation in the levels of squalene present in shark liver oils. In some species or under certain conditions, squalene may not be present at all or may reach levels of up to $95 \%$ in the oil. Deep-sea sharks use the high contents of squalene in their livers for buoyancy purposes. The coefficient of thermal expansion of squalene allows for an easy adjustment of the shark's weight to the actual water temperature associated with the depth at which the animal lives in the water (Pietsch and Jaeger, 2007).

Vitamin A analysis showed that different extraction conditions produced significantly different amounts of vitamin A, expressed as retinol equivalent (RE) and corresponding to 1 microgram of equivalent retinol per $\mathrm{mL}$ of sample (Fig 2.1, red bars). RE values among the various oils ranged from 578.98 to $3,682.01 \mathrm{RE} / \mathrm{g}$ of oil, which are considered to be very high. In commercial shark liver oil, the content found was $1,899.35 \mathrm{RE} / \mathrm{g}$ of oil. In this case, these results can be attributed to the refining process which the commercial oil is subjected to.

In the blue shark liver oil extracted by cooking methods, a value of $489 \mathrm{RE} / \mathrm{g}$ of oil was found, which was below the results of this research (Pacheco and Barrera-Arellano, 1994). The correlation between $\mathrm{CO}_{2}$ density and amount of vitamin $\mathrm{A}$ in oils was not significant $(95 \%$ confidence interval), indicating that other more relevant factors influenced the retinol yield.

The FAO stipulates that the minimum amount of vitamin A that fish oils must contain is $40 \mathrm{RE} /$ $\mathrm{mL}$ of oil. Thus, it can be seen that even the OFCA obtained via SFE with the lowest values have large amounts of vitamin A. According to Resolution RDC No. 269/2005, which addresses the recommended daily intake (RDI) of protein, vitamins, and minerals of ANVISA, the RDI of vitamin A for adults is $600 \mathrm{RE}$ (BRASIL, 2005). Thus, $1 \mathrm{~g}$ of OFCA either supplies the daily demand (conditions $300 \mathrm{bar} / 50^{\circ} \mathrm{C}$ and $300 \mathrm{bar} / 60^{\circ} \mathrm{C}$ ) or causes hypervitaminosis in the individual who consume it (other extraction conditions).

Solubility studies on vitamins in $\mathrm{CO}_{2} \mathrm{SC}$ were carried out by Johannsen and Brunner (1997) with vitamins $\mathrm{A}, \mathrm{D}, \mathrm{E}$, and $\mathrm{K}$. In this work, the influence of temperature and density on the solubility of these components was verified, showing that the temperature solubility of all substances increased with increasing density. This behavior was not observed for vitamin A extraction from blue shark liver oil.

Turner, King and Mathiasson (2001) argued that sometimes the solubility of pure compounds cannot be integrally applied to complex samples, as is the case of blue shark liver oil. In food products, fat-soluble vitamins are found in the same system as triacylglycerols and sterols, which may, in some cases, function as $\mathrm{CO}_{2}$-polarity modifiers and lead to different extraction conditions. Another important factor is that triacylglycerols are easily solubilized by $\mathrm{CO}_{2} \mathrm{SC}$ and, therefore, compete with other components present in the matrix.

\section{CONCLUSIONS}

The extraction and analysis of blue shark liver oil generated results of great importance in relation to the supercritical oil extraction yields (up to $60 \%$ ), demonstrating that excellent results can be obtained even without the use of organic solvents or high temperatures. The results of the physicochemical analyses indicate that the oils obtained, although not refined, have characteristics of processed oils and still comply with Brazilian and international regulations governing the safe consumption of these products. Analysis of the active compounds showed that this matrix is rich in essential fatty acids, in addition to containing squalene $(537 \mathrm{mg} / 100$ of oil) and vitamin A (maximum of 3,682 retinol equivalent/g of oil).

In summary, this research shows that blue shark liver, to the best of our knowledge, is a by-product of great nutritional importance and has potential for the purification of several types of products.

\section{ACKNOWLEDGMENTS}

The authors would like to thank FAPESP (State of São Paulo Research Foundation, Brazil) for financial support for the research $(2012 / 069810)$ and for the scholarship of D. N. Santos (2012/00467-3) and A. B. Verde (2013/18347-7). The authors also thank the technician Eng. Nilson. J. Ferreira for assistance with the analyses. The authors thank Dr. Mariana Gomes do Rêgo for help during the collection of sharks. 


\section{REFERENCES}

Abreu DAP, Losada PP, Maroto J, Cruz JM. 2011. Natural antioxidant active packaging film and its effect on lipid damage in frozen blue shark (Prionace glauca). Innov. Food Sci. Emerg. Technol. 12, 50-55. https://doi.org/10.1016/j. ifset.2010.12.006

Ahmed S, Elraies KA, Forooozesh J, Shafian SRBM, Hashmet MR, Hsia ICC, Almansour A. 2017. Experimental investigation of immiscible supercritical carbon dioxide foam rheology for improved oil recovery. J. Earth Sci. 28, 835-841. https://doi.org/10.1007/s12583-017-0803-z

Anschau V, Iaguer F. 2011. Avaliação da taxa de peroxidação lipídica em ratos suplementados com óleo de peixe e óleo de fígado de tubarão. Unoesc. \& Ciência - ACHS 2, 1 $17-30$.

Alves LMF, Nunes M, Marchand P, Le Bizec B, Mendes S, Correia JPS, Lemos MFL, Novais SC. 2016. Blue sharks (Prionace glauca) as bioindicators of pollution and health in the Atlantic Ocean: Contamination levels and biochemical stress responses. Sci. Total Environ. 563, 282-292. https://doi.org/10.1016/j.scitotenv.2016.04.085

AOAC. 2005. Official Methods of Analysis of AOAC INTERNATIONAL. 18th Ed., AOAC INTERNATIONAL, Gaithersburg, MD, USA, Official Method 991.39.

AOAC. 2005. Official Methods of Analysis of $A O A C$ INTERNATIONAL.18th Ed.,AOACINTERNATIONAL, Gaithersburg, MD, USA, Official Method 996.05.

Bakes MJ, Nichols PD. 1995. Lipid, fatty acid and squalene composition of liver oil from six species of deep-sea sharks collected in southern Australian waters. Comp. Biochem. Physiol. B Biochem. Mol. Biol. 110, 267-275. https://doi. org/10.1016/0305-0491(94)00083-7

Ballantyne JS. 1997. Jaws: The Inside Story. The Metabolism of Elasmobranch Fishes. Comp. Biochem. Physiol. B Biochem. Mol. Biol. 118, 703-742. https://doi.org/ 10.1016/S0305-0491(97)00272-1

Bartfai E, Orsière T, Duffaud F, Villani P, Pompili J, Botta A. 2000. Etude de l'effet genotoxique des huiles hépatiques brutes de trois espèces de requins méditerranéens par application du test de numération des micronoyaux dans les lymphocytes T humains. Ann. Biol. Clin. 58, 595-600.

Batista I, Nunes ML. 1992. Characterization of shark liver oils. Fish Res. 14, 329-334, https://doi.org/10.1016/0165-7836(92) 90041-Q

Boran G, Karaçam H, Boran M. 2006. Changes in the quality of fish oils due to storage temperature and time. Food Chem. 98, 693-698.

Bornatowski H, Schwingel PA. 2008. Alimentação e reprodução do tubarão-azul, Prionace glauca (LINNAEUS, 1758), capturado na costa Sudeste e Sul do Brasil. Arquivos de Ciências do Mar, Fortaleza 41, 98-103.

BRASIL. Agência Nacional de Vigilância Sanitária. Portaria ${ }^{\circ}$ 19 , de 15 de março de 1995 . Norma técnica para complemento nutricional. Diário Oficial de União, 16 de março de 1995.

BRASIL. Agência Nacional de Vigilância Sanitária. Resolução RDC $n^{\circ} 269$, de 22 de setembro de 2005. O regulamento técnico sobre a ingestão diária recomendada (IDR) de proteína, vitaminas e minerais. Diário Oficial da União, 23 de setembro de 2005.

Brunner G, Saure C, Buss D. 2009. Phase equilibrium of hydrogen, carbon dioxide, squalene, and squalane. J. Chem. Eng. Data 54, 1598-1609. https://doi.org/10.1021/je800926z

Canciam CA. 2010. Efeito da temperatura na viscosidade de óleos vegetais refinados. Publicatio UEPG: Ciências Exatas e da Terra 16, 07-12.

Cho Y, Kim T, Gil B. 2013. Correlation between refractive index of vegetable oils measured with surface plasmon resonance and acid values determined with the AOCS official method. Food Sc. Technol. 53, 517-521. https://doi.org/10.1016/j. lwt.2013.03.016

Corrêa APA, Peixoto CA, Gonçalves LAG, Cabral FA. 2008. Fractionation of fish oil with supercritical carbon dioxide. J. Food Eng. 88, 381-387. https://doi.org/10.1016/j. jfoodeng.2008.02.025
European Food Safety Authority (EFSA) 2010. Scientific Opinion on Fish Oil for Human Comsumption. Food Hygiene, including Rancididy. Panel on Biological Hazards (BIOHAZ). EFSAJ. 8, 10, 1874-1922.

European Pharmacopoeia. Cod-liver oil (type A). 2004. 5.ed. pdf Accessed 12/10/2014.

FAO. Food and Agriculture Organization. Codex Alimentarius Comission. In: Joint FAO/WHO Food Standards Programme Codex Commitee On Fats And Oils. 23. 2013. Langkawi, Malaysia. Proceedings. Rome, Italy, 2013. $12 \mathrm{p}$.

Fernández Ó, Vázquez L, Reglero G, Torres CF. 2013. Discrimination against diacylglycerol ethers in lipasecatalysed ethanolysis of shark liver oil. Food Chem. 36, 464 471. https://doi.org/10.1016/j.foodchem.2012.08.004

Ferrari CKB. 1998. Oxidação lipídica em alimentos e sistemas biológicos: mecanismos gerais e implicações nutricionais e patológicas. Rev. Nutr. 11, 3-14. https://doi.org/10.1590/ S1415-52731998000100001

Firestone D. ed. 2006. Physical and Chemical Characteristics of Oils, Fats, and Waxes. 2nd Ed. Washington: AOCS Press. 237p.

Fournier V, Destaillats F, Hug B, Golay PA, Joffre F, Juaneda P, Semon E, Dionisi F, Lambelet P, Sébédio JL, Berdeaux O. 2007. Quantification of eicosapentaenoic and docosahexaenoic acid geometrical isomers formed during fish oil deodorization by gas-liquid chromatography. J. Chromatogr. A 1154, 353-359. https://doi.org/10.1016/j. chroma.2007.03.099

García E, Gutierrez S, Nolasco H, Carreon L, Arjona O. 2006. Lipid composition of shark liver oil: effects of emulsifying and microencapsulation processes. Eur. Food Res. Technol. 222, 697-701. https://doi.org/10.1007/s00217-005-0129-4

García-Moreno PJ, Khanum M, Guadix A, Guadix EM. 2014. Antioxidant activity of protein hydrolysates obtained from discarded Mediterranean fish species. Food Res. Int. 65, 469-476. https://doi.org/10.1016/j.foodres.2014.03.061

Gava AJ. 2009. Princípios da Tecnologia de Alimentos. São Paulo: Nobel. 512p.

Gedi MA, Bakar J, Mariod AA. 2015. Optimization of supercritical carbon dioxide $\left(\mathrm{CO}_{2}\right)$ extraction of sardine (Sardinella lemuru Bleeker) oil using response surface methodology (RSM). Grasas Aceites 66, e074. https://doi.org/10.3989/ gya.0824142

Gironi F, Maschietti M. 2006. Separation of fish oils ethyl esters by means of supercritical carbon dioxide: Thermodynamic analysis and process modelling. Chem. Eng. Sci. 61, 5114-5126. https://doi.org/10.1016/j.ces.2006.03.041

Hajimoradi M, Hassan ZM, Pourfathollah AA, Daneshmandi S, Pakravan N. 2009. The effect of shark liver oil on the tumor infiltrating lymphocytes and cytokine pattern in mice. $J$. Ethnopharmacol. 126, 565-570. https://doi.org/10.1016/j. jep.2009.05.033

Hernández-Pérez M, Gallego RMR, Carlos MLG. 2002. Sex difference in liver-oil concentration in the deep-sea shark, Centroscymnus coelolepis. Marine and Freshwater Research 53, 883-886. https://doi.org/10.1071/MF01035

Igwe IO. 2004. The effects of temperature on the viscosity of vegetable oils in solution. Industrial Crops and Products 19, 185-190. https://doi.org/10.1016/j.indcrop.2003.09.006

Ivanovs K, Blumberga D. 2017. Extraction of fish oil using green extraction methods: a short review. Energy Procedia 128, 477-483. https://doi.org/10.1016/j.egypro.2017.09.033

Jayasinghe C, Gotoh N, Wada S. 2012. Regiospecific Analysis of Shark Liver Triacylglycerols. J. Am. Oil Chem. Soc. 89, 1873-1884. https://doi.org/10.1007/s11746-012-2081-3

Johannsen M, Brunner G. 1997. Solubilities of the Fat-Soluble Vitamins A, D, E, and K in Supercritical Carbon Dioxide. J. Chem. Eng. Data 42, 106-111. https://doi.org/10.1021/ je960219m

Kang SJ, Timmins MCA, Ackman RG. 1998. Similarities in the Lipid Class Profiles of Oils from Atlantic and Pacific Dogfish Livers. J. Am. Oil Chem. Soc. 75, 1667-1672. https://doi.org/10.1007/s11746-998-0109-5

Lisichkov K, Kuvendziev S, Zeković Z, Marinkovski M. 2014. Influence of operating parameters on the supercritical 
carbon dioxide extraction of bioactive components from common carp (Cyprinus carpio L.) viscera. Sep. Pur. Technol. 138, 191-197. https://doi.org/10.1016/j.seppur.2014.10.020

Lu, HT, Jiang, Y, Chen, F. 2003. Preparative separation and purification of squalene from the microalga Thraustochytrium ATCC 26185 by high-speed counter-current chromatography. J. Chromatogr. A 994, 37-43. https://doi.org/10.1016/ S0021-9673(03)00454-0

Magnusson CD, Haraldsson GG. 2011. Ether lipids. Chem. Phys. Lipids 164, 315- 340. https://doi.org/10.1016/j. chemphyslip.2011.04.010

Martinez-Correa HA, Gomes DCA, Kanehisa SL, Cabral FA. 2010. Measurements and thermodynamic modeling of the solubility of squalene in supercritical carbon dioxide. J. Food Eng. 96, 43-50. https://doi.org/10.1016/j. jfoodeng 2009.06.041

Nemeth M, Millesi E, Wagner KH, Wallner B. 2014. Effects of Diets High in Unsaturated Fatty Acids on Socially Induced Stress Responses in Guinea Pigs. PLoS One 9. 36-40. https://doi.org/10.1371/journal.pone.0120188

O'Brien RD. 2004. Fats and oils: formulating and processing for applications. CRC Press: Boca Raton, 574 p.

Pacheco MTB, Barrera-Arellano D. 1994. Fraccionamento del aceite de hígado de tiburón azul (Prionace glauca) y su estabilización con antioxidantes. Grasas Aceites 45 (3), 155-160.

Pietsch A, Jaeger P. 2007. Concentration of squalene from shark liver oil by short-path distillation. Eur. J. Lipid Sci. Technol. 109, 1077-1082. https://doi.org/10.1002/ejlt.200700039

Rubio-Rodríguez N, Diego SM, Beltrán S, Jaime I, Sanz MT, Rovira J. 2012. Supercritical fluid extraction of fish oil from fish by-products: A comparison with other extraction methods. J. Food Eng. 109, 238-248. https://doi. org/10.1016/j.jfoodeng.2011.10.011

Sahena F, Zaidul ISM, Jinap S, Jahurul MHA, Khatib A, Norulaini NAN. 2010. Extraction of fish oil from the skin of Indian mackerel using supercritical fluids. J. Food Eng. 99, 63-69. https://doi.org/10.1016/j.jfoodeng.2010.01.038

Santos DN, Takahashi EH, Verde AB, Oliveira AL. 2016. Supercritical extraction of cobia (Rachycentron canadum) liver oil as a new source of squalene. Food and Public Health 6, 157-164. https://doi.org/10.5923/j.fph.20160606.02

Schaschke C, Fletcher I, Glen N. 2013. Density and viscosity measurement of diesel fuels at combined high pressure and elevated temperature. Processes 1, 30-48. https://doi. org/10.3390/pr1020030
Shapiro H. 2003. Could n-3 polyunsaturated fatty acids reduce pathological pain by direct actions on the nervous system? Prostag. Leukotr. Ess. 68, 219-224. https://doi.org/10.1016/ S0952-3278(02)00273-9

Sunarya MH, Taylor KDA. 1996. Methods of extraction composition and stability of vitamin A and other components in dogfish (Squalus acanthias) liver oil. Food Chem. 55, 215-220. https://doi.org/10.1016/0308-8146(95)00109-3

Taher H, Al-Zuhair S, Al-Marzouqi AH, Haik Y, Farid M, Tariq S. 2014. Supercritical carbon dioxide extraction of microalgae lipid: Process optimization and laboratory scale-up. J. Supercrit. Fluids 86, 57-66. https://doi.org/10.1016/j. supflu.2013.11.020

Tavares R, Ortiz M, Rocha FA. 2012. Population structure, distribution and relative abundance of the blue shark (Prionace glauca) in the Caribbean Sea and adjacent waters of the North Atlantic. Fish Res. 129-130, 137-152. https:// doi.org/10.1016/j.fishres.2012.06.018

Tenuta-Filho A, Macedo L. 2015. Removal of Mercury from Shark Using Sodium Borohydride and Product Characterization. Int. J. Food Processing Technol. 2, 3441.

Turner C, King JW, Mathiasson L. 2001. Supercritical fluid extraction and chromatography for fat-soluble vitamin analysis. J. Chromatogr. A 936, 215-237.

Vázquez JA, Blanco M, Fraguas J, Pastrana L, Pérez-Martín R. 2016. Optimisation of the extraction and purification of chondroitin sulphate from head by-products of Prionace glauca by environmental friendly processes. Food Chem. 198, 28-35, https://doi.org/10.1016/j.foodchem. 2015.10.087

Vögler R, Beier E, Ortega-García S, Santana-Hernández H, Valdez-Flores JJ.2012. Ecological patterns, distribution and population structure of Prionace glauca (Chondrichthyes: Carcharhinidae) in the tropical-subtropical transition zone of the north-eastern Pacific. Mar. Environ. Res. 73, 37-52. https://doi.org/10.1016/j.marenvres.2011. 10.009

Xu WL, Huang YB, Qian JH, Sha O, Wang YQ. 2005. Separation and purification of stigmasterol and $\beta$-sitosterol from phytosterol mixtures by solvent crystallization method. Sep. Pur. Technol. 41, 173-178. https://doi.org/10.1016/j. seppur.2004.02.005

Zenebon O, Pascuet NS, Tiglea P. coord. 2008 Instituto Adolfo Lutz. Métodos físico-químicos para análise de alimentos. 4 ed, 1ed digital. São Paulo, 1020p. 